\title{
"Effective decisions for individualized assessment and minimization of the risk of unfriendly takeover of enterprises: the features of the game theory application"
}

\begin{tabular}{|c|c|}
\hline AUTHORS & $\begin{array}{l}\text { Oksana Korolovych } \\
\text { Olha Chabaniuk } \\
\text { Natalia Ostapiuk } \\
\text { Yurii Kotviakovskyi } \\
\text { Nelia Gut }\end{array}$ \\
\hline ARTICLE INFO & $\begin{array}{l}\text { Oksana Korolovych, Olha Chabaniuk, Natalia Ostapiuk, Yurii Kotviakovskyi and } \\
\text { Nelia Gut (2019). Effective decisions for individualized assessment and } \\
\text { minimization of the risk of unfriendly takeover of enterprises: the features of the } \\
\text { game theory application. Problems and Perspectives in Management, 17(1), 370- } \\
\text { 379. doi:10.21511/ppm.17(1).2019.32 }\end{array}$ \\
\hline DOI & http://dx.doi.org/10.21511/ppm.17(1).2019.32 \\
\hline RELEASED ON & Wednesday, 03 April 2019 \\
\hline RECEIVED ON & Sunday, 17 February 2019 \\
\hline ACCEPTED ON & Tuesday, 26 March 2019 \\
\hline LICENSE & $\begin{array}{l}(\boldsymbol{c c}) \mathbf{E Y} \\
\text { This work is licensed under a Creative Commons Attribution } 4.0 \text { International } \\
\text { License }\end{array}$ \\
\hline JOURNAL & "Problems and Perspectives in Management" \\
\hline ISSN PRINT & $1727-7051$ \\
\hline ISSN ONLINE & $1810-5467$ \\
\hline PUBLISHER & LLC "Consulting Publishing Company "Business Perspectives" \\
\hline FOUNDER & LLC "Consulting Publishing Company "Business Perspectives" \\
\hline
\end{tabular}

NUMBER OF REFERENCES

20
NUMBER OF FIGURES

1
NUMBER OF TABLES

3

(C) The author(s) 2023. This publication is an open access article. 


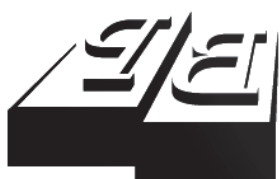

BUSINESS PERSPECTIVES

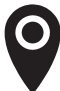

LLC "CPC "Business Perspectives" Hryhorii Skovoroda lane, 10, Sumy, 40022, Ukraine

www.businessperspectives.org

Received on: $17^{\text {th }}$ of February, 2019 Accepted on: $26^{\text {th }}$ of March, 2019

(c) Oksana Korolovych, Olha Chabaniuk, Natalia Ostapiuk, Yurii Kotviakovskyi, Nelia Gut, 2019

Oksana Korolovych, Ph.D. in Economics, Associate Professor, Mukachevo State University, Ukraine.

Olha Chabaniuk, Ph.D. in Economics, Associate Professor of Accounting and Taxation Department, Kyiv National Economic University named after Vadym Hetman, Ukraine.

Natalia Ostapiuk, Doctor of Economic Sciences, Professor, Sopot High School, Poland.

Yurii Kotviakovskyi, Associate Professor of the Law Faculty, Sumy National Agrarian University, Ukraine.

Nelia Gut, Ph.D. (Law), Assistant Professor of the Department of Constitutional Law, Taras Shevchenko National University of Kyiv, Ukraine.

\section{(c) (i)}

This is an Open Access article, distributed under the terms of the Creative Commons Attribution 4.0 International license, which permits unrestricted re-use, distribution, and reproduction in any medium, provided the original work is properly cited.
Oksana Korolovych (Ukraine), Olha Chabaniuk (Ukraine),

Natalia Ostapiuk (Poland), Yurii Kotviakovskyi (Ukraine), Nelia Gut (Ukraine)

\section{EFFECTIVE DECISIONS FOR} INDIVIDUALIZED ASSESSMENT AND MINIMIZATION OF THE RISK OF UNFRIENDLY TAKEOVER OF ENTERPRISES: THE FEATURES OF THE GAME THEORY APPLICATION

\begin{abstract}
The conditions for doing business at this stage are often similar in a game in which you need to calculate your actions a few steps ahead. At the same time, it is important to highlight several possible current options and make the necessary decision at the control moment. Moreover, each of the options formed should be justified, understandable and take into account the risk factors and available resources.

Today, the main problem of assessing and minimizing the risk of "unfriendly takeover" is due to the fact that in most cases the raider is a player who acts quite legitimately and relies on the loopholes of the current legislative framework. Therefore, it is easier to identify possible actions of the raider and to avoid them within the limits of the reverse game than to deal with the consequences.
\end{abstract}

The purpose of the research is to study the specificity of the individualized assessment and minimization of the risk of "unfriendly takeover" by using elements of game theory.

It has been taken into account that the effect of individualization in assessing the risk of unfriendly takeover of enterprises can possibly be achieved on the basis of the application of game theory, the elements of which provide simulation of the unfriendly takeover process within the mathematical description of the inherent combinations of attack/defence as if they actually occurred in time both within one state of the external environment and for their given set.

The results allowed forming mathematical decision-making models based on the elements of the antagonistic game "raider-target enterprise" and "raider games with the external environment", which proved the possibility to: 1) identify possible functions of wins/losses; 2) combinations of attacks that can be neglected (that is, from the point of view of the rationality of decisions, will be rejected by the raider); 3 ) the ranking of the raider's "attack combinations" for the reliability of their use during "unfriendly takeover". Under such conditions, the target company can provide not only a detailed assessment, but also an effective minimization of the risk of "unfriendly takeover" and allocate the best combination of protection.

\section{Keywords}

\section{JEL Classification} payment matrix, unfriendly takeover, raider, target enterprise

C50, C13, D74, C 70, D81

\section{INTRODUCTION}

Management of business processes in the conditions of permanent uncertainty and constant change of external and internal factors of management obliges to develop a flexible mechanism for preparing and making managerial decisions. Of course, it must contain a powerful analytical tool for the development of information affecting the solu- 
tion and its consequences. In complex structures, the theory of games is an important tool. Moreover, the decisive condition for successful operation and observance of the principle of continuous operation of the business unit is the construction of models of behavior of competitors, actions of possible conflicting parties. The latter will be able to provide business security and strategic decision-making.

The term "unfriendly takeover" appeared at the turn of the XIX and XX centuries, along with the shares that made it possible for a person or group of cooperating people to exercise corporate control over an enterprise in the form of a joint stock company, in spite of the will and in the face of a rigid opposition from the administration or the owner (or co-owners) of the share package that provides such control (Zelenytsia, 2012, p. 146). In Ukraine, this term has its own specificity, because it is used as a synonym for "raidering" (Nechay, 2009), which provides for a much wider arsenal of enterprise takeover schemes, including criminal methods of capture during a planned conflict, in accordance with a certain scenario with a false legal justification, in particular is realized with simulation of observance of procedures established by law or by means of power capture (Bartkiv, 2012). As an example, an attempt was made to take over the central market "Ozerka" in Dnipropetrovsk (owned by LLC "RegionOptServis") in 2005, during which 90 people were arrested.

It should be noted that in 2015 , there were about 3 thousand cases of unfriendly takeover in our country, of which 2.7 thousand were successful and applied not only "white", "grey", but also "black" schemes (Nechay, 2009). In 2016, the situation was not better, during this period only in the 1st quarter over 1,000 complaints about the actions of registrars related to "black" raid were received. At the same time, if the criminal method of seizure involves criminal liability (according to the Law of Ukraine "On Amendments and Additions to Certain Legislative Acts of Ukraine, regarding the establishment of criminal liability for seizure of enterprises (raiding)" No. 3300), the other types of raider attacks are entirely legal. Moreover, known national players such as Privat group, Finance and Credit Group; Consortium of Alfa Group; System Capital Management; JSCIB "Ukrsibbank"; financial group "TAS”, "Slavutich-Capital" company and "Interpipe" corporation do not mind the tools of "white" and "gray" raidering. At the same time, the precondition for unfriendly takeovers is not only the imperfection of the legislative framework (which was not even corrected by the Law "On State Registration of Rights to Real Estate", enacted in 2016, aimed at introducing mechanisms for monitoring the activities of registrars and notaries), but also the lack of a single approach to assessing and minimizing the risk of such takeovers (which would help in a timely manner to stop the raiders and help management to formulate a mechanism for appropriate protection).

We note that the main problem of risk assessment and minimization of "unfriendly takeovers" is due to the fact that in most cases a raider is a player who acts quite legitimately and relies on loopholes in the current legislative framework. In particular, using opportunities to buy shares or debts of the enterprise (in order to launch artificial insolvency mechanisms or sanation procedures), manipulations with the register of owners, court decisions, etc. Therefore, it is possible to prevent such takeover within the framework of the reverse game. Typical examples are the attempts of ZAO "Sarmat" management to eliminate the unfriendly takeover of "Obolon" CJSC in 2003 (due to the purchase of shares at an overcharge price) or the stopping of the sales of Dnipropetrovsk butter extraction plant Bunge Ltd (according to the decision of the Solomensky District Court on obligations of Ukrpatent to register TM "Oleina" to a third party in 2008).

\section{LITERATURE REVIEW}

The problems of risk assessment and minimization of unfriendly takeovers of the enterprise are covered in the writings of Ukrainian authors such as Dykan and Zaytseva (2009), Virchenko (2011), Burbelo et al. (2015). Interest in this problem is inherent to a number of foreign scientists, in particular: Schröter (2008), Sogrina (2010), Vershinin (2008). For the most part, the outlined 
scientists propose different approaches to solving such a problem, but most of them are based solely on identifying factors that the raider could potentially take into account. In particular, Dykan and Zaytseva (2009), Schröter (2008), Vershynin (2008) who suggest using a risk profile of an unfriendly takeover of an enterprise aimed at identifying its attractiveness for raiders, based on the characteristics of profitability, liquidity of assets and the possibility of obtaining control over its resources. Sogrina (2010), Vyrchenko (2011, pp. 236244) draw attention to the need to identify a class of unfriendly risk of takeover on the basis of the total coefficient, taking into account the combined effect of a large number of determinants, grouped according to factors such as "organizational structure", "ownership", "management and shareholders," external environment" and average value according to the factor "financial and economic condition".

Due to the lack of a unified approach to the problem under investigation, the studies identified are the subject of analysis by a number of well-known researchers, including Burbelo et al. (2015, pp. 99116), Ilchenko and Grischenko (2011), Oleksyuk (2017). In the majority of cases, they emphasize the fact that even if all factors that have already been identified for the takeover, it is important for the company to have an adequate counteraction system to the outlined process. In particular, the raider can give up intentions, if the unfriendly takeover of the business will cost more than legal purchase (Oleksyuk, 2017).

For this purpose, Ilchenko and Grischenko (2011) recommend to pay attention not only to the factors that the raider can potentially take into account, but also to the level of protection of the enterprise from unfriendly takeovers. Accordingly, there are grounds for reviewing the specifics of the assessment and minimization of the risk of unfriendly takeovers of enterprises, because even if all factors taken into account by the raider are detected, their minimization is rather complicated process.

On the other hand, raider attack is developed individually for each enterprise with prediction of the necessary correction (Oleksyuk, 2017). Therefore, we believe that the risk in this case is individualized (that is, it takes into account the "possible fail- ure" of protecting the enterprise from unfriendly takeovers, but in the context of a specific list of "dangers" and "combinations of protection" inherent in this entity of economic activity).

The purpose of the paper is to investigate the specifics of individualized evaluation and minimize the risk of unfriendly takeovers by using the elements of game theory, as well as the maximum justification of management decisions aimed at economic security of business.

\section{THE MAIN RESULTS OF THE STUDY}

For an individualized assessment and minimization of the risk of unfriendly takeover of the enterprise, we have chosen an approach based on the application of the game theory. This method was chosen because elements of the outlined theory allow:

1) to implement a simulation of the unfriendly takeover process by means of a mathematical description of the attack/protection combinations inherent to it, as if they would actually occur in time, both within one state of the external environment, and for their given set;

2) to change the nature of imitation within the limits of several types of decision-making mathematical models that are oriented on specificity (Bartish \& Dudzyaniy, 2009): "antagonistic (non-cooperative) game", which is conditioned by the presence of a conflict of interests that neutralizes the aspirations of participants for any interaction. A typical example is an attempt to unfriendly take over the business center "Horizon Park" (Kyiv, 2016), connected with the conflict of interests of Ukrsotsbank (included in the UniCredit group) and the company "Project-A", as well as to unfriendly take over the shopping and entertainment center SkyMall (Kiev, 2005), which is the result of confronting the interests of Arricano and Stockman; "Game with nature", which is due to the implementation of unfriendly takeover for the obligatory interaction of the raider with the environment, within which unfriendly takeover is carried 
out. This is due to the fact that the latter may affect both the course and the result of the process of unfriendly takeover. Thus, the successful unfriendly takeover of the SkyMall shopping and entertainment canter (Kiev, 2005) jeopardized the decision of the London International Court of Arbitration of 2016 (according to which Stockman should return the trading and entertainment center SkyMall to the property of Arricano);

3) to take into account the specifics of the interaction of players. Mathematical models of decision-making should be formed, based on the specificity of initiating an unfriendly takeover game, in particular (Burbelo et al., 2015, pp. 105-107): the management of the enterprise (or the target enterprise of any form of ownership) is potentially entering into a game in the presence of attractive assets for resale (real estate, equipment, land), the validity of the enterprise for the formation of large regional or national holdings in highly liquid industries (as evidenced by high profitability of business); possible advantages of competitors from stopping the working object (in the case of a competitive struggle); space for raider actions (presence of "weaknesses"); the raider is likely to enter the game with information on the "weaknesses" inherent in the target company, which are related to: absence of controlling stake or insufficient level of consolidation of authorized capital; availability of open access to confidential information regarding shareholders and financial and economic activities of the enterprise; violations of the legislation by the enterprise in the course of their activities; the lack of duly completed accounting and documentation, the presence of double-counting; the presence of conflicts caused by the implementation of economic relations at the enterprise; underestimation of the market value of their own assets, their own position in the market and competitors; the presence in the structure of property assets with insufficiently clearly defined property rights or issued to fictitious subsidiaries; lack of mutual understanding of the management with the owners of the enterprise; irresponsible attitude of enter- prise management to possible raider attacks, the existence of a shadow economy and corruption; the presence of uncontrolled accounts payable and overdue liabilities.

Figure 1 shows an algorithm for individualized assessment and minimization of hostile enterprise takeover risks by using the elements of game theory.

According to the algorithm, we have identified the main principles of the practical organization of the outlined process. In particular:

1) use of the mathematical model of the antagonistic (non-cooperative) "raider-target enterprise" game, as the basis for an individualized assessment and minimization of unfriendly takeover risks;

2) processing the data of the mathematical model, based on the orientation of the players on rational decisions (based on optimal combinations of protection/attack) and the opposite idea of gain/loss;

3) systematic description of an antagonistic (non-cooperative) game in the form of two-level "payment matrices" that summarize all possible functions of winnings/losses;

4) dependence of the number of two-level "payment matrices" on the number of game situations.

At the next stage of the study, we have illustrated the specificity of an individualized assessment and minimization of the risks of unfriendly takeovers of the enterprise based on the application of the game theory. This is ensured during its practical testing, on the example of PJSC "Transcarpathia - Auto", for which there is a risk of unfriendly takeover (through buying shares) by LLC "TENT TRANS". Individualization is achieved within the framework of taking into account the following list of peculiarities of the game:

- formation of the 1st level of "payment matrices", taking into account that raiders have the possibility of buying shares from $1 \%$ to $41 \%$. This is appropriate in reducing their 


\begin{tabular}{|c|c|}
\hline \multicolumn{2}{|c|}{$\begin{array}{l}\text { DETERMINATION OF THE BASIS FOR AN INDIVIDUALIZED ASSESSMENT } \\
\text { AND MINIMIZATION OF THE RISKS OF "UNFRIENDLY TAKEOVERS" }\end{array}$} \\
\hline$\downarrow$ & $\downarrow$ \\
\hline $\begin{array}{l}\text { Based on the specifics of the initiation } \\
\text { of the game (a list of factors in which each } \\
\text { player comes into play) }\end{array}$ & $\begin{array}{l}\text { Based on the interests of the participants } \\
\text { of the game in time, within the limits of one state } \\
\text { of the external environment (or their given set) }\end{array}$ \\
\hline$\downarrow$ & $\downarrow$ \\
\hline \multicolumn{2}{|c|}{$\begin{array}{l}\text { Mathematical description of inherent in this process unfriendly takeover } \\
\text { of probabilistic values of winnings/losses according to each combination of defence/attack }\end{array}$} \\
\hline \multicolumn{2}{|c|}{$\downarrow$} \\
\hline \multicolumn{2}{|c|}{$\begin{array}{l}\text { Construction within the mathematical model of the antagonistic (non-cooperative) game "raider-target enterprise" } \\
\text { 1) "payment matrices" (the number of which is determined by the space for the actions of the raider); } \\
\text { 2) the aggregated payment matrix. }\end{array}$} \\
\hline \multicolumn{2}{|c|}{ 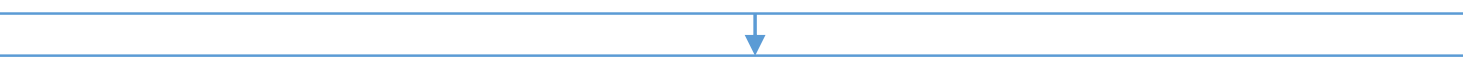 } \\
\hline \multicolumn{2}{|c|}{$\begin{array}{l}\text { 1) Data process in identification of situations that, from the point of view of rationality of decisions, will be } \\
\text { rejected by the raider; } \\
\text { 2) the definition of "attack combinations", which is most likely to be included in the scenario of "unfriendly takeover". }\end{array}$} \\
\hline \multicolumn{2}{|c|}{$\downarrow$} \\
\hline \multicolumn{2}{|c|}{$\begin{array}{l}\text { Construction of a preventive system of enterprise protection against "unfriendly takeovers" in the following areas: } \\
\text { 1) formation of a system for protecting insider information; } \\
\text { 2) work with constituent and other documents; } \\
\text { 3) adjusting the personnel policy (to simulate the managers of the enterprise for effective work) } \\
\text { 4) working with majority and minority shareholders; } \\
\text { 5) management of accounts payable; } \\
\text { 6) asset protection, etc. }\end{array}$} \\
\hline
\end{tabular}

Figure 1. Algorithm of individualized estimation and minimization of risks of unfriendly takeovers of the enterprise

market value, according to one of these "combinations of attack": a public negative financial analysis of the target enterprise, using a number of other technical indicators $\left(B_{1}\right)$; public litigation against the shareholders of the target enterprise $\left(B_{2}\right)$; public condemnation of inefficiency of target enterprise management $\left(B_{3}\right)$; the use of greenmail technology $\left(B_{4}\right)$;

- the formation of the 2 nd level of "payment matrices", based on the content of their 1st level. The level summarizes the "combination of protection" of the target enterprise, which will be in the quest to minimize capital fragmentation by redemption of own shares and their resale to majority shareholders;

- the definition, as the goal of the players, of further maximizing value of the acquired se- curities, is detailed by the probability values of the wins/losses for each combination of defense/attack (with a certain degree of the colt, which identifies the magnitude of the risk of applying combinations in accordance with the values of the coefficient of variation $\gamma)$.

Based on the features of the game, Table 1 shows the 2-level payment matrix of LLC "TENT TRANS" - PJSC “Transcarpathia Auto”, which implements a further study in the context of all possible "combinations of attack/protection" that are possible with a decrease in the value of shares, subject to a public negative financial analysis "target enterprise" $\left(B_{1}\right)$. At the same time, for the purpose of illustrating the results, the basic algorithms for calculating quantitative indicators regarding the options for winning/losing are also reflected below. 
Table 1. Payment matrix of LLC "TENT TRANS" - PJSC "Transcarpathia Auto", based on the actions of the raider $\mathrm{B} 1$, thousand $\mathrm{UAH}$

Source: Calculated by author based on Bartish and Dudzyaniy (2009).

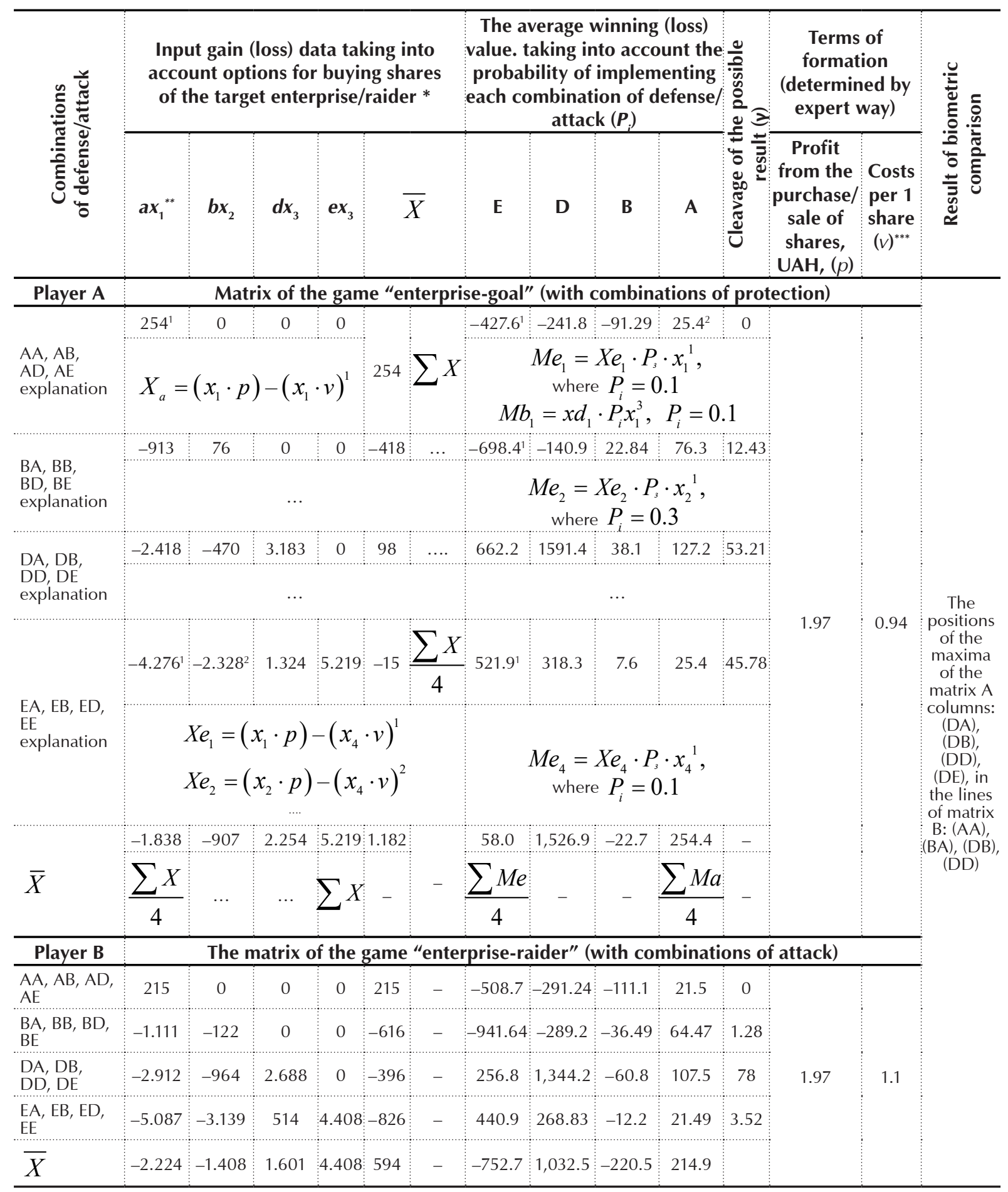

Note: 1 At the same time, if the value of the indicator is up to $10 \%$, the risk of fluctuations is weak; from 10 to $20 \%$ - the risk of variation is average; higher than $20 \%$ - high fluctuation risk (Bartish \& Dudzyaniy, 2009), * - the volume of buying up shares $\left(\mathrm{x}_{\mathrm{i}}\right)$, at the level of $1-2 \%$ or in the amount of 247 thousand units. $\left(\mathrm{ax}_{1}\right)$ at the level of $10 \%$ or in the volume of 1,236 thousand units, $\left(b x_{2}\right)$ at the level of $25 \%$ or in the amount of 3,090 thousand units; at the level of $14 \%$ or in the amount of 5,067 thousand units. ${ }^{*}-\left(\mathrm{ax}_{1}\right)$ the struggle of players for the right to speak on behalf of the shareholder (which makes it possible to obtain the necessary decisions in the courts); $\left(b x_{2}\right)$ the struggle of players for the right to initiate a meeting of shareholders with a "necessary" agenda, in particular, by changing the management of the enterprise; $\left(d x_{3}\right)$ struggle for players to block the decision to change the governing bodies of PJSC "Transcarpathia Auto"; $\left(e x_{3}\right)$ the struggle of players for a controlling stake, ${ }^{* *}-$ it is assumed that the expenses, calculated for 1 share, the participants of the game bear in any case. 
It should be noted that in case of any unfriendly takeover, a situation with a "non-zero sum" is possible, that is, all participants in such a process can become a winner/loser. Therefore, in Table 1, among the basic elements of the payment matrix, the elements of the bimatrix comparison are highlighted, together with the combinations outlined in it (Article 14), and the players' risk zones (gray zones), depending on each of them, are identified.

The introduction of such elements for each $A_{i} B_{j}$ game situation and each A/B player involves a calculation of the possibilities of mutual win/lose $\left(a_{i j}\right)$, as well as determining the set of optimal situations (white zones), also according to the Nash equilibrium parameter (by which each participant chooses the combination of protection/attack that is optimal for him, but provided that the other participant adheres to a certain reciprocal combination).
At the same time, Nash equilibrium is not always the most optimal for players (for example, if a loss is predicted), in this case, it is said that this situation is not Pareto optimal. For example, the implementation of a bimetric comparison, according to Table 1, indicates that the combination of DB determines the equilibrium situation in which both the raider and the target enterprise will receive the largest gain from the purchase of shares at a price below the par value, even if there are additional costs for conducting operations. This situation is both Nash equilibrium and Pareto-optimal, but the value of the coefficient of variation predicting significant fluctuations in such a gain neutralizes the attractiveness of the combination of $\mathrm{DB}$ for each player. Thus, it is not expedient to use the given value to substantiate strategic further decisions, since the result of calculations does not satisfy the requests of both the player and the target enterprise.

Table 2. Aggregated payment matrix of LLC "TENT TRANS" - PJSC "Transcarpathia Auto", thousand UAH

Source: Calculated by author based on Bartish and Dudzyaniy (2009).

\begin{tabular}{|c|c|c|c|c|c|c|c|c|c|c|c|c|}
\hline \multirow{2}{*}{\multicolumn{2}{|c|}{$\begin{array}{l}\text { A group of } \\
\text { combinations } \\
\text { of attacks/ } \\
\text { code }\end{array}$}} & \multicolumn{4}{|c|}{$\begin{array}{c}\text { The average winning/losing } \\
\text { value, taking into account } \\
\text { the probability of realizing } \\
\text { each combination of player } B \\
\text { attack }\end{array}$} & \multirow{3}{*}{$\begin{array}{c}\text { Fluctuation } \\
\text { of the } \\
\text { possible } \\
\text { result } \\
(v) \\
0\end{array}$} & \multicolumn{4}{|c|}{$\begin{array}{l}\text { The average winning/ } \\
\text { losing value, taking into } \\
\text { account the probability } \\
\text { of implementing each } \\
\text { combination of player } A \\
\text { protection }\end{array}$} & \multirow{3}{*}{$\begin{array}{c}\begin{array}{c}\text { Fluctuation } \\
\text { of the } \\
\text { possible } \\
\text { result }\end{array} \\
0\end{array}$} & \multirow[t]{2}{*}{$\begin{array}{l}\text { Result } \\
\text { of bimatric } \\
\text { comparison } \\
\text { (with the } \\
\text { allocation } \\
\text { of Nash } \\
\text { equilibrium) }\end{array}$} \\
\hline & & $\mathbf{E}$ & D & B & A & & E & D & B & A & & \\
\hline \multirow{4}{*}{ B1 } & A1 & -508.7 & -291.24 & -111.1 & 21.5 & & -427.6 & -241.8 & -91.29 & 25.4 & & \multirow{4}{*}{$\begin{array}{l}\text { PMA1: EA, DD, } \\
\text { EB, DA, PMB1: } \\
\text { AA, BA, DA, EA }\end{array}$} \\
\hline & A2 & -941.64 & -289.2 & -36.49 & 64.47 & 1.28 & -698.4 & -140.9 & 22.84 & 76.3 & 12.43 & \\
\hline & A3 & 256.8 & $1,344.2$ & -60.8 & 107.5 & 78 & 662.2 & 1591.4 & 38.1 & 127.2 & 53.21 & \\
\hline & A4 & 440.9 & 268.83 & -12.2 & 21.49 & 3.52 & 521.9 & 318.3 & 7.6 & 25.4 & 45.78 & \\
\hline \multirow{4}{*}{ B2 } & A5 & $-1,783.9$ & $-1,072.1$ & -420.1 & -48.6 & 0 & -588.1 & -342.9 & -128.4 & 9.6 & 0 & \multirow{4}{*}{$\begin{array}{l}\text { PMA: EE, DB2, } \\
\text { DD, ED, PMB: } \\
\text { AA, BB, DB2, EE }\end{array}$} \\
\hline & A6 & $-4,867.9$ & $-2,732.8$ & -963.6 & -145.9 & 0.08 & $-1,280.5$ & -545 & -88.5 & 28.9 & 0.71 & \\
\hline & A7 & $-6,602.3$ & $-3,043.7$ & -1605 & -243.3 & 8.2 & -623.2 & 602.5 & -147.5 & 48.2 & 370 & \\
\hline & A8 & -998.2 & -608.7 & -321.2 & -48.6 & 3.6 & 197.6 & 120.51 & -29.5 & 9.6 & 0.95 & \\
\hline \multirow{4}{*}{ B3 } & A9 & -213.6 & -118.7 & -34.5 & 17.8 & 0 & -304.3 & -173.8 & -56.8 & 13.8 & 0 & \multirow{4}{*}{$\begin{array}{l}\text { PMA: EE2, DB2, } \\
\text { DD, ED, PMB: } \\
A A, B B, D B 2, E E 2\end{array}$} \\
\hline & A10 & -284.7 & 0 & 193.2 & 53.4 & 0.51 & -550.9 & -159.4 & 126.4 & 41.5 & 0.88 & \\
\hline & A11 & 637.9 & 1,112 & 322 & 88.9 & 31.76 & 212.79 & 865 & 210.7 & 69.2 & 55.11 & \\
\hline & A12 & 364.8 & 222.5 & 64.4 & 17.8 & 3.6 & 283.75 & 173 & 42.2 & 13.8 & 3.6 & \\
\hline \multirow{4}{*}{ B4 } & A13 & -402.7 & -228.7 & -83.9 & 21.49 & 0 & -605.5 & -407.8 & -99.3 & -124 & 0 & \multirow{4}{*}{$\begin{array}{l}\text { PMA: AA, AB, } \\
\text { DD, AE, EA, PMB: } \\
\text { AE, BE, DB, EE }\end{array}$} \\
\hline & A14 & -688.8 & -166.8 & 45 & 64.5 & 5.53 & -3003 & $-2,410$ & -1.2 & -371 & 5.53 & \\
\hline & A15 & 474.27 & 1,344 & 75 & 107.5 & 1.21 & $-8,714$ & $-7,725$ & -2 & -618 & 1.21 & \\
\hline & A16 & 440.8 & 268.8 & 15 & 21.49 & 3.6 & $-2,534$ & $-1,545$ & -0.4 & -124 & 3.6 & \\
\hline
\end{tabular}

Note: 1 - The positions of the maxima of the matrix A (PMA) columns, the positions of the maxima in the lines of the matrix $\mathrm{B}(\mathrm{PMB})$, according to the codes of the attack/protection combinations used in Table 1 (col. 1). 2 - B2 - a combination of DB, defines the equilibrium situation of Nash, in which the target company receives a winnings UAH 48.2 thousand, and the raider the least damage UAH -243.3 thousand. (hence the use of the group of "combinations of attack" is not Pareto-optimal for raider, which is associated with significantly higher court and pre-trial costs); B3 - there are 2 equilibrium combinations: EE in which the target company wins UAH 283.75 thousand, and the raider - UAH 364.8 thousand; DB for which the target enterprise wins UAH 865 thousand, and the raider - UAH 1112 thousand. In fact, participation in such a game, from the point of view of rational decision-making, is acceptable for the raider; B4 - a combination of AA, defines the equilibrium situation of Nash, in which the "target company" has a minimum loss UAH -124 thousand, and the raider wins only UAH 21.49 thousand (hence the participation in such a game is not Pareto-optimal for the target enterprise). 
According to the logic of the antagonistic game of hostile takeover by LLC “TENT TRANS" - PJSC "Transcarpathia-Auto", two-level "payment matrices" should be provided for all other "combinations of defense/attack". The data obtained, for the sake of the complexity of the presentation of data, should be summarized in an aggregated form (Table 2), which necessarily determines the situations that, in terms of rationality of decisions, will be rejected by the raider. In particular:

1) with the balance of the Nash (which is not Pareto-optimal for the raider);

2) the situation of the "grey zone" (with high risk of winning/losing fluctuations) for each group of protection / attack combinations.

When initiating an unfriendly takeover process, its specificity is determined by the raider, but its actions are characterized by a certain degree of uncertainty, since they are additionally adjusted by such factors as the "combination of protection" of the target enterprise and the reaction of the en- vironment. Thus, the applied interest is the addition of the aggregated payment matrix (see Table 2) to the assessment of the effectiveness of the raider action under uncertainty. This is possible with the help of the "game of nature" tools (such as the Bayesian criterion $\sum\left(a_{i j} p_{j}\right)$, the Wald criterion $\min \left(a_{i}\right)$, the Sevidge criterion $\max \left(a_{i j}\right)$ or the Hodge-Lehman $W_{i}$ criterion is also a means of ranking the effectiveness of "combinations of attacks", taking into account the effect of the combination of factors of uncertainty, as illustrated by the data in Table 3.

The results of the calculation of the criteria point to the uniqueness of the results, which identify the high risk of using, in the preparation and conduct of the unfriendly takeover of the "Greenwood" scheme by PJSC "Transcarpathia Auto". At the same time, this situation is not typical, and the data of the criteria may be contradictory, in connection with the specifics of their calculation. For example, the Wald criterion is targeted at the best "raid combination" of the raider, based on the assumption that the external environment will be

Table 3. The results of the estimation of the attack combinations of LLC "TENT TRANS" according to the probability of use during hostile takeover, thousand UAH

Source: Calculated by author based on Bartish and Dudzyaniy (2009).

\begin{tabular}{|c|c|c|c|c|c|c|c|}
\hline \multicolumn{2}{|c|}{ Code according to } & \multicolumn{4}{|c|}{$\begin{array}{l}\text { Definition of "combinations of attack", which } \\
\text { most likely will be included in the "unfriendly } \\
\text { takeover" scenario }\end{array}$} & \multirow{2}{*}{$\begin{array}{c}\text { Aggregate } \\
\text { effectiveness } \\
\text { of attack } \\
\text { combinations } \\
\text { (ranked) }\end{array}$} & \multirow{2}{*}{$\begin{array}{l}\text { The risk } \\
\text { of raider } \\
\text { takeover }^{5}\end{array}$} \\
\hline $\begin{array}{c}\operatorname{Re} \\
\text { distribution }\end{array}$ & $\begin{array}{l}\text { Aggregated } \\
\text { payment } \\
\text { matrix }\end{array}$ & $\begin{array}{l}\text { Bayesian } \\
\text { criterion } \\
\sum\left(a_{i j} p_{j}\right)^{1} \\
\end{array}$ & $\begin{array}{l}\text { Wald } \\
\text { criterion } \\
\min \left(a_{i j}\right)^{2}\end{array}$ & $\begin{array}{l}\text { Sevige } \\
\text { criterion, } \\
\max \left(a_{i j}\right)^{4}\end{array}$ & $\begin{array}{l}\text { Hodge- } \\
\text { Lehman, } \\
W_{i}^{3}\end{array}$ & & \\
\hline $\mathrm{A} 1$ & A1 & -191.642 & -508.7 & 1635.24 & -350.17 & 9 & Low \\
\hline A2 & A2 & -192.722 & -941.64 & 1633.2 & -567.181 & 10 & Low \\
\hline A3 & A4 & 120.788 & -12.2 & 1075.17 & 54.294 & 4 & Average \\
\hline A4 & A9 & -72.44 & -213.6 & 1462.7 & -143.02 & 6 & Average \\
\hline A5 & A10 & 73.47 & -284.7 & 1344 & -105.615 & 5 & Average \\
\hline A6 & A12 & 137.21 & 17.8 & 1121.5 & 77.505 & 2 & High \\
\hline A7 & A13 & -148.681 & -402.7 & 1572.7 & -275.6905 & 8 & Low \\
\hline A8 & A14 & -89.97 & -688.8 & 1510.8 & -389.385 & 7 & Average \\
\hline A9 & A15 & 498.877 & 75 & 118.2 & 286.9385 & 1 & High \\
\hline $\mathrm{A} 10$ & A16 & 134.369 & 15 & 1075.2 & 74.6845 & 3 & High \\
\hline
\end{tabular}

Notes: 1 - anticipates the desire of player B to $a_{\text {. }}$ actions, which maximizes the average gain and minimizes the average risk $\mathrm{r}$ (or actions with the maximum value of $\Sigma\left(a_{i j} p_{j}\right)$. The results of calculating the values of $\Sigma\left(a_{i j} p_{j}\right)$ allow selecting from its possible $\Sigma\left(a_{i} p_{j}\right)$ its maximal element $\max =498.88 .2$ - outlines the most likely combination of the raider, provided that he follows the logic of the solutions, in which the combination which, in the worst conditions, guarantees the maximum gain, i.e. $a=$ max (min $\left.a_{i j}\right)$, is rational. The results of calculating the min $\left(a_{i j}\right)$ values allow selecting from the possible min $\left(a_{i j}\right)$ the maximal element $\max =75.3$ - requires the selection of the maximum result $\max =286.9385$ (which corresponds to actions A9). $4-$ allows the enterprise to detect a combination of attack, in which the raider suffers minimal expenses (provided $a=\min \left(\right.$ max $r_{i j}$ ). The possibility of such a forecast is due to the fact that the Sevidge criterion expresses the most pessimistic nature's response to the influence of the raider. Under the above conditions, with a minimal consequence, there is a risk 118.2. 5 - the higher the rank, the lower the risk of a raider's winning, identified within the scale: high, average, low. 
the least sensitive to its impact, and the Sevidge criterion outlines those that will lead to minimal losses. Therefore, in the absence of the identity of the results, the "enterprise objectives" conclusions regarding the risks of using separate schemes of unfriendly takeovers are taken with due regard to the strengths and weaknesses of the raider.

Based on the foregoing, such calculations may become indicators of a solution that will not be effective. At the same time, the obtained indicators are useful from the point of view of internal and external factors, conditions of capture for raider. With the help of the above mentioned values of the coefficients responsible for the preparation of the management solution, it is possible to cut off unprofitable options for the actions of the managers, as well as identify the necessary measures to enhance the security of the enterprise.

\section{CONCLUSION}

The results of the application of the game theory elements allowed forming mathematical decision-making models based on the elements of the antagonistic game "raider-target enterprise" and "raider's game with the external environment", which proved the ability to:

1) identify possible functions of winnings/losses and build a system of actions that increase the security of the enterprise, promptly indicating possible immediate actions by the invaders;

2) combine attacks that can be neglected (that is, those that, in terms of rationality of solutions, will be rejected by the raider);

3) rank "racket combinations" against the possibility of their use during unfriendly takeover (which allows outlining its scheme).

Under such conditions, the target company can provide not only a detailed assessment but also an effective minimization of the risk of hostile takeovers and outline the best combination of protection. The use of these models contributes to the formation of a system of comprehensive substantiation of management decisions in the conditions of instability of the external business environment.

\section{REFERENCES}

1. Bahamid, R. A., \& Doh, S. I. (2017). A review of risk management process in construction projects of developing countries. IOP Conf. Series: Materials Science and Engineering, 271. Retrieved from https://doi.org/10.1088/1757899X/271/1/012042

2. Bartish, M. Ya., \& Dudzyaniy, I. М. (2009). Дослідження операцій. Ухвалення рішень і теорія ігор [Doslidzhennia operatsii. Ukhvalennia rishen i teoriia ihor] (278 p.). Lviv: Vydavnychyi tsentr LNU im. Ivana Franka.

3. Bartkiv, O. M. (2012). Чорне рейдерство як спосіб захоплення [Chorne reiderstvo yak sposib zakhoplennia pidpryiemstva]. Stratehichni orientiry. Retrieved from http://libfor.com/ index.php? newsid $=1722$

4. Biliak, Y. V. (2013). Причини зростання масштабів рейдерських захоплень в Україні: причини виникнення, типи і види рейдерських схем [Prychyny zrostannia masshtabiv reiderskykh zakhoplen v Ukraini: prychyny vynyknennia, typy i vydy reiderskykh skhem]. Investitsii: praktyka ta dosvid, 12, 44-48. Retrieved from http://www.investplan.com.ua/pdf/12_2013/13.pdf

5. Borek A., Parlikad, A. K., Webb, J., \& Woodall, P. (2014). Introduction to Enterprise Risk Management (Chapter 4). In Total Information Risk Management: Maximizing the Value of Data and Information Assets. https://doi.org/10.1016/ B978-0-12-405547-6.00004-3

6. Burbelo, O. A. (Ed.), Ramazanova, S. K. (Ed.), Zaets, O. M., Gudima, T. S., \& Kuzmenko О. М. (2015). Економічна безпека підприємства в умовах рейдерських загроз [Ekonomichna bezpeka pidpryiemstva $v$ reiderskykh zahrozakh] (285 p.). Severodonetsk: Vydavnytstvo "SNU imeni Dalya". Retrieved from http://www.iepd.kiev.ua/ wp-content/uploads/2014/03/ maket-1.pdf 
7. Debnath, A., Bandyopadhyay, A., Roy, J., \& Kar, S. (2018). Game theory based multi criteria decision making problem under uncertainty: a case study on Indian tea industry. Journal of Business Economics and Management, 19(1), 154-175. https://doi.org/10. 3846/16111699.2017.1401553

8. Dikan, V. L., \& Zaytseva, I. Y. (2009). Оцінка та аналіз рівня захисту підприємств автотранспорту від недружніх поглинань на основі економікоматематичних методів [Otsinka ta analiz rivnia zakhystu pidpryiemstv avtotransportu vid nedruzhnoho pohlynannia na osnovi ekonomiko-matematychnykh metodiv]. Visnyk ekonomiki transportu i promyslovosti, 26, 76-85.

9. Ilchenko, Yu. V., \& Grischenko, А. О. (2011). Оцінка методологічних підходів вимірювання рівня захисту підприємств від ворожих поглинань [Otsinka metodolohichnykh pidkhodiv vymiriuvannia rivnya zakhystu pidpryiemstv vid vorozhykh pohlynan]. Zbirnyk naukovykh prats Natsionalnoho tehnichnoho universitetu, 24(1), 318-321.

10. Marks, N. (2015). World-Class Risk Management (234 p.). North Charleston: Create Space Independent Publishing Platform. Retrieved from https://www.amazon. com/World-Class-Risk-Management-Norman-Marks-ebook/dp/ B00ZLMF0JS

11. Myšková, R., \& Doupalová, V. (2015). Approach to Risk
Management Decision-Making in the Small Business. Procedia Economics and Finance, 34, 329-336. Retrieved from https://doi.org/10.1016/S22125671(15)01637-8

12. Nechay, V. O. (2009). Схеми недружнього поглинання (рейдерство) [Skhemy nedruzhnoho pohlynannia (reiderstvo)]. Efektyvna ekonomika, 4. Retrieved from http://www.economy.nayka. com.ua/?op $=1 \& \mathrm{z}=93$

13. Oleksyuk, N. V. (2017). Методu захисту від корпоративного рейдерства [Metody zakhystu vid korporatyvnoho reiderstva]. Retrieved from http://intkonf.org/ oleksyuk-nv-metodi-zahistu-vidkorporativnogo-reyderstva/

14. Schröter, H. G. (Ed.) (2008). The European Enterprise: Historical Investigation into a Future Species (81 p.). New York: Springer Science and Business Media. Retrieved from https://epdf.tips/ the-european-enterprise-historical-investigation-into-a-futurespeciesb561959dd508ded06585a4 a506610d743265.html

15. Sogrina, N. S. (2010). Методика оценки риска недружественного поглощения (рейдерства) в трансформируемой экономике [Metodika otsenki riska nedruzhestvennogo pogloshcheniya (reyderstva) $\mathrm{v}$ transformiruyemoy ekonomike]. Nauchnyy vestnik Chelyabinskogo gosudarstvennogo universiteta, 5(25), 166-172. Retrieved from https://cyberleninka.ru/article/v/ metodika-otsenki-riska-nedru- zhestvennogo-pogloscheniyareyderstva-v-transformiruemoyekonomike

16. Sum, R. M. (2013). Risk management decision making. In Proceedings of the International Symposium on the Analytic Hierarchy Process 2013, at Kuala Lumpur. Retrieved from http://www.isahp. org/uploads/47.pdf

17. Vershinin, А. V. (2008). Методика оценки риска недружественного поглощения для предприятия [Metodika otsenki riska nedruzhestvennogo pogloshcheniya dlya predpriyatiya]. Nauchnyy vestnik Kazanskogo tehnologicheskogo universiteta, 6, 280-284.

18. Virchenko, V.V. (2011). Передумови та методи недружнього поглинання суб〉єктів господарювання [Peredumovy ta metody nedruzhnoho pohlynannia subiektiv hospodariuvannia]. Teoretychni ta prykladni pitannia ekonomiky, 24, 236-244

19. Wu, D., Olsen, D. L., \& Dolgui, A. (2015). Decision making in enterprise risk management: A review and introduction to special issue. Omega, 57(A), 1-4. https://doi. org/10.1016/j.omega.2015.04.011

20. Zelenytsia, I. М. (2012). Захист прав учасників корпорацій від недружніх поглинань [Zakhyst prav uchasnykiv korporatsiy vid nedruzhnikh pohlynan]. Naukovyi visnyk Natsionalnoho tehnichnoho universitetu Ukrainy, 3(15), 146150. Retrieved from http://www. sociology.kpi.ua/wp-content/uploads/2014/05/3-15-2012.pdf 